\title{
Long-term release of carbon dioxide from arctic tundra ecosystems in Alaska
}

\author{
Euskirchen, E.S ${ }^{\mathrm{a}^{*}}$, M.S. Bret-Harte ${ }^{\mathrm{a}}$, G.R. Shaver ${ }^{\mathrm{b}}$, C.W. Edgar ${ }^{\mathrm{a}}$, V.E. Romanovsky ${ }^{\mathrm{c}, \mathrm{d}}$
}

\author{
${ }^{a}$ University of Alaska Fairbanks, Institute of Arctic Biology, Fairbanks, AK, USA 99775 \\ ${ }^{b}$ The Ecosystems Center, Marine Biological Laboratory, Woods Hole, MA, USA 02543 \\ ${ }^{c}$ University of Alaska Fairbanks, Geophysical Institute, Fairbanks, AK, USA 99775 \\ ${ }^{\mathrm{d}}$ Tyumen State Oil and Gas University, Tyumen, Russia \\ *Corresponding Author, seeuskirchen@ alaska.edu, 907-474-1958
}

\section{Author Contributions}

E.S.E, M.S.B.H., and G.R.S. conceived the micrometeorological study and scientific objectives. V.E.R. designed and installed the borehole temperature measurements and analyzed the data. E.S.E. and C.W.E. processed and analyzed the micrometeorological data. M.S.B.H. and C.W.E. collected, processed and analyzed the soil $\mathrm{C}$ data. All authors commented on the analysis and presentation of the data. E.S.E wrote the paper with contributions from all authors.

Short Title: Long-Term Arctic Tundra Carbon Fluxes 


\begin{abstract}
Releases of the greenhouse gases carbon dioxide $\left(\mathrm{CO}_{2}\right)$ and methane $\left(\mathrm{CH}_{4}\right)$ from thawing permafrost are expected to be among the largest feedbacks to climate from arctic ecosystems. However, the current net carbon (C) balance of terrestrial arctic ecosystems is unknown. Recent studies suggest that these ecosystems are sources, sinks, or approximately in balance at present. This uncertainty arises because there are few long-term continuous measurements of arctic tundra $\mathrm{CO}_{2}$ fluxes over the full annual cycle. Here, we describe a pattern of $\mathrm{CO}_{2}$ loss based on the longest continuous record of direct measurements of $\mathrm{CO}_{2}$ fluxes in the Alaskan Arctic, from two representative tundra ecosystems, wet sedge and heath tundra. We also report on a shorter time series of continuous measurements from a third ecosystem, tussock tundra. The amount of $\mathrm{CO}_{2}$ loss from both heath and wet sedge ecosystems was related to the timing of freeze-up of the soil active layer in the fall. Wet sedge tundra lost the most $\mathrm{CO}_{2}$ during the anomalously warm autumn periods of September - December 2013 - 2015, with $\mathrm{CH}_{4}$ emissions contributing little to the overall $\mathrm{C}$ budget. Losses of $\mathrm{C}$ translated to approximately $4.1 \%$ and $1.4 \%$ of the total soil $\mathrm{C}$ stocks in active layer of the wet sedge and heath tundra, respectively, from $2008-2015$. Increases in air temperature and soil temperatures at all depths may trigger a new trajectory of $\mathrm{CO}_{2}$ release, which will be a significant feedback to further warming if it is representative of larger areas of the Arctic.
\end{abstract}

Keywords: Arctic tundra, net ecosystem exchange, permafrost, soil temperature, carbon dioxide, methane 


\section{Introduction}

In the Arctic, the rate of climate change is now faster than ecosystems can naturally adapt (Duarte et al., 2012). Mean annual air temperature is currently $1.5^{\circ} \mathrm{C}$ higher than the $1971-2000$ mean, with the greatest increases having occurred in the autumn and winter (Jeffries et al., 2013). This warming in the Arctic is more than double the warming at lower latitudes (Overland et al., 2013). In a changing arctic climate, one of the most significant potential feedbacks from terrestrial ecosystems to the atmosphere is carbon release from decomposition of soil organic matter (SOM) that was until recently frozen in permafrost (Schuur et al., 2015).

Arctic tundra ecosystems underlain by permafrost store large amounts of soil organic $\mathrm{C}$ in the first several meters of the soil because decomposition rates are low in the seasonally unfrozen active layer of these cold, often wet soils (Hugelius et al., 2014). Under a warming climate, thawing of the upper permafrost will add soil organic $\mathrm{C}$ to the active layer, thereby increasing the pool of SOM potentially available for decomposition. In northern Alaska, this formerly frozen SOM is labile and could become available for microbial degradation as the active layer continues to deepen (Mueller et al., 2015). However, the net $\mathrm{C}$ balance of these ecosystems will be controlled by the balance between potential gains in plant productivity, which may also increase under warming (Shaver et al., 1991; Natali et al., 2012) and losses through SOM decomposition and lateral export of carbon.

Recent data syntheses and modeling studies of arctic tundra net $\mathrm{CO}_{2}$ balance have suggested that the tundra is either presently a $\mathrm{CO}_{2}$ sink, a source, or approximately in balance (McGuire et al., 2012; Belshe et al., 2013; Fisher et al., 2014). In a data synthesis, Belshe et al. (2013) found that tundra has been a source of $\mathrm{CO}_{2}$ over the last 40 years, despite increases in summer gross primary productivity since the 1990s. In a synthesis of ground-based C flux observations, bottom-up process-based models, and top-down atmospheric inverse models, McGuire et al. (2012) found that tundra has been a sink to neutral for $\mathrm{CO}_{2}$ in recent decades. In a large cross-comparison among 40 terrestrial biosphere models simulated over the Alaskan Arctic, Fisher et al. (2014) found no consensus, with different models showing the Alaskan Arctic as a sink, a source, or in balance. These studies agree that there is insufficient continuous $\mathrm{CO}_{2}$ flux data from tundra ecosystems to understand the current $\mathrm{C}$ balance in arctic tundra, and to parameterize and validate ecosystem models, particularly during the winter and shoulder seasons. It has long been recognized that winter $\mathrm{CO}_{2}$ efflux is a key component of the annual $\mathrm{C}$ 
budget in arctic ecosystems because microbes can continue to respire under the snowpack in temperatures close to and even below freezing (Coyne \& Kelley, 1971; Panikov et al., 2006; Drotz et al., 2010), but the magnitude and interannual variability of this winter flux remains uncertain (Björkman et al., 2010; Webb et al., 2016). Due to a harsh, remote environment and the difficulties of collecting measurements in areas without line power, continuous measurements of arctic tundra $\mathrm{CO}_{2}$ fluxes over the full annual cycle across numerous years have not existed until recently (Euskirchen et al., 2012; Lüers et al., 2014; Oechel et al., 2014).

Arctic wetlands have been implicated as a major source of $\mathrm{CH}_{4}$ (McGuire et al., 2009), a powerful greenhouse gas. But again, much uncertainty exists with regard to arctic $\mathrm{CH}_{4}$ flux (Christensen et al., 2014). Some field studies indicate substantial current Arctic emissions and suggest that future Arctic emissions may also be large (O'Conner et al., 2010; Nauta et al., 2015), and that these emissions may explain the recent increase in global atmospheric $\mathrm{CH}_{4}$ (Dlugokencky et al., 2009). While $\mathrm{CH}_{4}$ has rarely been measured during the snow season, a recent study indicates that winter $\mathrm{CH}_{4}$ emissions are greater than previously estimated, with highest emissions from dry, upland tundra (Zona et al., 2016). However, other data from airborne studies suggest that sources of $\mathrm{CH}_{4}$ in Arctic Alaska may not be particularly large (Chang et al., 2014).

We measured net ecosystem exchange of $\mathrm{CO}_{2}$ (NEE, where a negative value denotes a terrestrial sink) over eight years (2008 - 2015) in the Imnavait Creek Watershed in northern Alaska $\left(68^{\circ} 37^{\prime} \mathrm{N}, 149^{\circ} 18^{\prime} \mathrm{W}\right)$ at two ecosystems, heath and wet sedge tundra. These continuing eddy covariance measurements comprise the longest continuous record of Alaskan arctic tundra NEE that is currently available. We also measured NEE over eight growing seasons and two full years at another ecosystem in this watershed, tussock tundra. In 2012, we initiated growing and shoulder season $\mathrm{CH}_{4}$ eddy covariance measurements at the wet sedge tundra site. Beginning in 2006, we measured permafrost temperatures at a nearby borehole in the same watershed, thereby permitting us to relate long-term change in soil temperatures at various depths to $\mathrm{C}$ flux. We also quantified the amount of soil carbon in the annually thawed active layer at our study sites, allowing us to estimate the amount of soil carbon that is lost or gained from the system over the period of measurement. 


\section{Materials and Methods}

\section{Study site}

The study site is located in the Imnavait Creek watershed $\left(2.2 \mathrm{~km}^{2}\right)$, in the northern foothills of the Brooks Range, Alaska ( $\left.68^{\circ} 37^{\prime} \mathrm{N}, 149^{\circ} 18^{\prime} \mathrm{W}\right)$. The watershed is underlain by continuous permafrost, to a maximum thickness of $250-300 \mathrm{~m}$ (Osterkamp et al., 2005). The predominant soils are $15-20 \mathrm{~cm}$ of organic peat underlain by silt and glacial till (Hinzman et al., 1991). The mean annual air temperature for the years $1988-2007$ was $-7.4^{\circ} \mathrm{C}$ and the mean annual precipitation was $318 \mathrm{~mm}$, with about $40 \%$ occurring as rain and $60 \%$ as snow. The landscape is treeless, located $\sim 100 \mathrm{~km}$ north from latitudinal treeline.

We examined three different tundra types, including heath, moist acidic tussock, and wet sedge tundra. The moist acidic tussock tundra ecosystem is dominated by the tussock-forming sedge Eriophorum vaginatum, Sphagnum spp., deciduous dwarf shrubs such as Betula nana and Salix spp., and evergreen dwarf shrubs such as Rhododendron subarcticum (formerly known as Ledum palustre) and Vaccinium vitis-idaea. The dry heath tundra ecosystem is dominated by Dryas integrifolia, lichen, Carex spp., and dwarf evergreen and deciduous shrubs. The wet sedge ecosystem includes a variety of Carex species, Eriophorum angustifolium and dwarf deciduous shrubs such as Betula nana, Salix spp and mosses. Further information on the vegetation at these sites can be found in Euskirchen et al. (2012) and Kade et al. (2012).

For scaling the vegetation and flux measurements, we relied on the descriptions and estimated area from Jorgensen and Heiner's (2004) vegetation map, which covers the 300,000 $\mathrm{km}^{2}$ of the North Slope of Alaska, from the Brooks Range to the Arctic Ocean. In this map, our tussock tundra site corresponds to tussock tundra on non-sandy substrates, our heath tundra site corresponds to prostrate dwarf-shrub, graminoid, sedge, forb, and lichen communities, excluding that found in the higher elevations of the Brooks Range, and our wet sedge tundra site corresponds to wet sedge, moss communities on the North Slope (excluding those in the far north of the Arctic Coastal Plain, which are assumed to differ from those found on the North Slope; Table 1).

\section{Eddy covariance data collection}

Our time series of eddy covariance data builds on that described in Euskirchen et al. (2012). Due to the remote location of the site and the absence of line power, electrical power for the equipment at the site was provided by solar panels, wind turbines, and batteries. For the wet 
sedge and heath tundra sites, the power supply at each site consisted of $326-\mathrm{V}$ deep cycle marine batteries connected to five 130-W solar panels and a wind turbine. The solar panels were the predominant source of power from April to October. The wind turbine was the main source from November-March. From 2008 to 2012, the power supply at the tussock tundra site consisted of three $12-\mathrm{V}$ deep cycle marine batteries connected to six solar panels totaling $300 \mathrm{~W}$ and consequently only operated from approximately May to early November. In 2013, a wind turbine and additional batteries were added to the tussock tundra site, thereby permitting year-round operations.

The eddy covariance system for measuring the fluxes of $\mathrm{CO}_{2}$, water, and energy was placed on a $3 \mathrm{~m}$ high tripod in the center of each site. The instrumentation consisted of a 3-D sonic anemometer (CSAT-3; Campbell Scientific Instruments, Logan, Utah, USA) mounted at a height of $2.5 \mathrm{~m}$ at all three sites. An open-path infrared gas analyzer (LI-7500 IRGA; LI-COR, 2004; Lincoln, Nebraska, USA) was used at all three sites until 2012. At this time, the LI-7500A IRGA (LI-COR, 2009), which is not subject to sensor heating, as can be the case with the LI7500 IRGA, (discussed below), was installed at the wet sedge site. The LI-7500 IRGA remained at the heath tundra site, but with the addition in 2013 of the enclosed path LI-7200 IRGA (LICOR, 2010). The main axes of the IRGAs were tilted by $20^{\circ}$ with respect to the horizontal to aid in draining condensation and precipitation from the optical windows. The IRGAs and the CSAT3 sonic anemometers were both mounted on a shared horizontal bar and were laterally separated by $20 \mathrm{~cm}$ to reduce flux loss and flow distortion. The differing time delays in signals were taken into account by shifting the CSAT-3 data by one scan (at $10 \mathrm{~Hz}$ ) to match the fixed $302.369 \mathrm{~ms}$ delay (or 3 scans at $10 \mathrm{~Hz}$ ) that is programmed into the LI-7500 or LI-7500A. This instrumentation was connected to a digital datalogging system (either a CR3000 or CR5000; Campbell Scientific Instruments) to log data at $10 \mathrm{~Hz}$ intervals. Raw data were collected once a month from a CompactFlash card located in the datalogger. The IRGAs were calibrated following the instructions in the manuals (LI-COR 2004, 2009, 2010a, b). Calibration was checked during each site visit. Gas analyzers were calibrated monthly at first, although this frequency was reduced to every several (3-4 months) since inspections indicated that the instruments remained stable over a several month period.

The percentage of data collected was near 95\% during the months from April - October. Data collection from the months November to March was near 85\%, except for some larger gaps 
in the data in the beginning months of data collection, when data loss was greater (Table 2). Data coverage during the entire period was approximately $68 \%$ after accounting for data loss from power outages, automatic gain control (which represents optical impedance by precipitation or aerial contaminants) and filtering for periods of low turbulence (friction velocity, $\mathrm{u}^{*} \leq 0.1$ ). The fast-response $(10 \mathrm{~Hz})$ eddy covariance was reduced to half-hourly means.

To account for nocturnal $\mathrm{CO}_{2}$ advection, we calculated a storage term (Papale et al., 2006) and then gap-filled the data removed when $\mathrm{u}^{*} \leq 0.1$. The storage term had a negligible, $\leq 2 \%$ effect, on the net annual fluxes. We use the ReddyProc tool for gap-filling of the eddy covariance data (Reichstein et al., 2005). The gap-filling of the eddy covariance and meteorological data are performed through methods that are similar to Falge et al. (2001), but also consider both the co-variation of fluxes with meteorological variables and the temporal auto-correlation of the fluxes (Reichstein et al., 2005). The Webb-Pearman-Leuning ('WPL') terms were applied during post-processing to the $\mathrm{CO}_{2}$ and latent heat fluxes to account for changes in mass flow caused by changes in air density (Webb et al., 1980). In addition, corrections were applied to account for frequency attenuation of the eddy covariance fluxes (Massman 2000, 2001). We used the EddyPro 4.2 software (LI-COR, 2013) to apply the WPL and frequency corrections, and to reduce the fast-response $(10 \mathrm{~Hz})$ eddy covariance data to $30-$ minute means. Our choice of ReddyProc and EddyPro software for use in data processing complies with Fratini and Mauduer (2014), who recommend relying only on data processing software that has been extensively documented and validated.

To evaluate the influence of surface heating on the open-path LI-COR 7500 IRGA (Burba et al., 2008), we collected data using both an open- and enclosed-path analyzer during 2013 and 2014 at the heath tundra site. As noted above, in addition to the LI-COR 7500 open-path instrument that had been in use since the beginning of the study, we installed an enclosed path LI-COR-7200 in 2013. The enclosed path LI-7200 is not subject to surface heating issues. We ran the LI-COR 7200 instrument nearly continuously, except for gaps in 2013 between September 14-25 and October 10 - December 1, and in 2014 between May 5 - June 6 and September 29 - October 10. These data gaps occurred due to instrument malfunction when it had to be brought in from the field site for repair. The LI-7500 ran continuously except for September 15 - 26, 2013 (Table 2). 
Data collected under normal operating conditions may still need to be discarded from both instruments, although the two instruments are subject to data loss for different reasons. The enclosed path LI-7200 is subject to some data loss to the frequency dampening (but less than some closed-path models due to a shorter intake tube), and may also be subject to incomplete temperature attenuation even in the short tube. In arctic environments, the icing can occur on the inside of the intake tube of the instrument. The LI-7500 is subject to data loss due to precipitation on the analyzer. The eddy covariance computation from both analyzers is subject to data loss due to precipitation on the sonic anemometer.

We compared the LI-7200 and LI-7500 datasets using common half-hourly periods of data acquisition in 2013 and 2014. We found that overall the LI-7500 showed slight uptake of $\mathrm{CO}_{2}$ during the winter, while the LI-7200 showed release (Fig. 1a). Upon application of the heating correction (Burba et al., 2008) the LI-7500 and LI-7200 analyzers generally agreed well in the winter (Fig. 1a). The correction was negligible in the summer. We note that our magnitude of correction $\left(\sim 0.45 \mu \mathrm{mol} \mathrm{m}{ }^{-2} \mathrm{~s}^{-1}\right.$; Fig. 1b) is in line with, or slightly smaller than, that discussed in Burba (2008), Burba and Anderson (2010), and Oechel et al. (2014). The effect of increasing air temperatures at our study sites on the sensor heating correction would seemingly result in a smaller correction to the original open-path LI-7500 data since the sensor and the ambient air temperature would be closer together, as was seen in the warmer months (Fig. 1a). In summary, based on our comparison between the open- and enclosed-path analyzers, we determined that the sensor heating correction was a warranted, and necessary, adjustment to the open-path LI-7500 data.

Data pertaining to $\mathrm{CH}_{4}$ fluxes were collected seasonally at the wet sedge site, beginning in July 2012. The site was instrumented with a with a fast-response open-path methane analyzer (LI-7700; LI-COR, 2010b), which used a LI-7550 interface unit to control mirror heating and cleaning cycles and to route the high-frequency data to the datalogger. The calculated methane fluxes exclude data during heating and cleaning, and when the available optical power was $<15 \%{ }^{33}$. The raw fluxes are also filtered to remove all periods where $\mathrm{u}^{*}<0.1$, and momentum flux > 0. Gaps in the $\mathrm{CH}_{4}$ data, generally due to brief power outages or filtering, were filled by calculating the mean diurnal variation, where a missing observation is replaced by the mean for that time period (half hour) based on adjacent days. The $\mathrm{CH}_{4}$ data were converted to $\mathrm{CO}_{2}$ equivalents $\left(\mathrm{CO}_{2} \mathrm{e}\right)$ by multiplying the $\mathrm{CH}_{4}$ flux by the 100 -year global warming potential of 
methane, estimated at 28 (Myhre et al., 2013), taking into account that this conversion is performed on the masses of the gases, not the masses of $\mathrm{C}$.

\section{Borehole Measurements}

The $70 \mathrm{~m}$ borehole was drilled in spring 2006, at the top of the Imnavait Creek valley west-facing slope. The temperature is measured every 5 minutes at $0.34,0.5,0.9,3,4,5,7,10$, $15,20,30,40,50$, and $60 \mathrm{~m}$ depths and the hourly averaged data were stored by the datalogger (Campbell Scientific Instruments, Logan, UT). Temperatures at 0.34, 0.5, and $0.9 \mathrm{~m}$ were measured in a separate shallow borehole. The precision of temperature measurements is better than $0.05^{\circ} \mathrm{C}$. Soil temperatures at depths of $0.34,0.5$, and $0.9 \mathrm{~m}$ were averaged in determining complete soil freeze or thaw. The date of complete soil freeze was determined by the mean day after which soil temperatures remained below $-0.1^{\circ} \mathrm{C}$ at depths to $0.9 \mathrm{~m}$. The date of soil thaw was determined to be the day after which soil temperatures remained above $+0.1^{\circ} \mathrm{C}$ at depths to $0.9 \mathrm{~m}$.

\section{Partitioning of Net Ecosystem Exchange into Gross Primary Productivity and Ecosystem Respiration}

NEE represents the balance between gross $\mathrm{CO}_{2}$ assimilation (gross primary productivity, GPP, where GPP $\leq 0$, since $\mathrm{CO}_{2}$ uptake is denoted as a negative value) and ecosystem respiration (ER). While we do not directly measure GPP and ER, NEE based on eddy covariance data can be partitioned into these counterparts to provide an approximation of GPP and ER, and consequently a broader understanding of the photosynthetic versus respiratory controls over NEE. This partitioning is calculated from the relation between NEE during the nighttime (defined as photosynthetically active radiation $<50 \mu \mathrm{mol} \mathrm{m}^{-2} \mathrm{~s}^{-1}$ ) and air temperature, fit to an equation:

$\mathrm{ER}=\mathrm{R}_{0} * \mathrm{Q}_{10}{ }^{\mathrm{Ta} / 10}$,

where $\mathrm{T}_{\mathrm{a}}=$ air temperature, $\mathrm{R}_{0}$ is a scale parameter, and $\mathrm{Q}_{10}$ is the temperature sensitivity coefficient of ER. $\mathrm{R}_{0}$ and $\mathrm{Q}_{10}$ were estimated each day using a 29-day moving window and least squares method (Ueyama et al., 2013). GPP is then calculated as GPP $=$ NEE - ER. We calculated ER and GPP for the June - August growing season.

\section{Error Estimate}

Bootstrapping was used to estimate the error (95\% confidence interval) about the total NEE, GPP, and ER values over the measurement periods for both $\mathrm{CO}_{2}$ and $\mathrm{CH}_{4}$ using SAS 
software version 9.4. The bootstrap calculated the confidence interval by (1) constructing 2,000 bootstrapped sample series by randomly sampling with replacement the observed total daily time series, (2) calculating an average from each constructed data series, and (3) calculating the grand mean $( \pm 95 \% \mathrm{CI})$ from the distribution of means calculated from the bootstrapped data series (Ebron and Tibshirani, 1998).

\section{Trend Analysis}

We assessed trends in metrics related to our soil temperature time series, including day of freeze in the autumn, annual minimum soil temperature, the day of thaw in the spring and the duration of the zero curtain. The zero curtain is the period during soil freeze-up where the phase transition of water to ice is retarded due to latent heat release. Here, we examined the zero curtain period where soil temperatures to 0.9 m depth remained between -0.1 and $+0.1^{\circ} \mathrm{C}$. We also assessed trends in the summer fluxes of NEE, GPP, and ER. To perform this trend analysis, we first tested for autocorrelation in the time series using the autocorrelation and partial autocorrelation functions (acf, pacf in R software version 3.2.3). We detected a positive autocorrelation of lag-1 in the metrics related to soil temperature, while the summer fluxes of NEE, GPP, and ER did not show autocorrelation. We then pre-whitened the soil temperature metrics to remove the lag-1 autocorrelation using the Yue and Pilon method (Yue et al., 2002) in the zyp package of R. We applied the non-parametric Mann-Kendall test for trend at the 5\% significance level on the data with the lag-1 autocorrelation removed, as well the flux data without the autocorrelation. We also computed the magnitude of the trend (e.g., a trendline with a slope) based on the Theil-Sen approach (Sen, 1968).

\section{Soil Carbon Determination}

From July 25-28, 2013, soils were sampled at 20 points in a stratified random manner within the major plant community types in the eddy covariance footprint of each tower. To determine soil bulk density and element concentrations, organic soil horizons were sampled volumetrically with a serrated knife. Soil monoliths (approximately 5 x $5 \mathrm{~cm}$ and extending from surface of the green moss to the organic-mineral interface) were cut from the side of a soil pit. Cores (5.4 cm diameter) were taken through the mineral soil horizon below these monoliths to the ice surface at the bottom of the thawed layer. Monoliths and cores were wrapped in tin foil to preserve structure, returned to the lab, and refrigerated prior to analysis. Within 24 hours of collection, monoliths and cores were processed to determine bulk density, soil moisture, and C 
content.

Soil samples from monoliths and cores were homogenized by hand, and coarse organic materials (twigs and roots more than $2.5 \mathrm{~cm}$ in diameter) and rocks were removed. The soil $\mathrm{C}$ stocks were corrected for rocks by calculating the volume and mass of the removed rocks. Coarse fractions and a $10 \mathrm{~g}$ subsample of the fine soil fractions were weighed wet, dried at $60^{\circ} \mathrm{C}$ for $48 \mathrm{~h}$ and reweighed for dry matter content, then ground using a ball mill (organic samples; SPEX Certiprep 8000-D, SPEX, Inc. Metuchen, NJ) or mortar and pestle (mineral soils). Dry matter content of fine mineral soil was determined on subsamples dried at $105{ }^{\circ} \mathrm{C}$ for $48 \mathrm{~h}$. For all samples dried at $60^{\circ} \mathrm{C}, \mathrm{C}$ content was measured using a Leco TruSpec CHN Analyzer (LECO, Inc., St. Joseph, MI). The volume of each organic monolith layer or mineral core was calculated as depth multiplied by area minus rock volume. Bulk density and $\mathrm{C}$ pools were calculated separately for mineral and organic horizons, and $\mathrm{C}$ pools were then summed for each sampling point. C pools for each tower were averages weighted by the areas of the major plant community types sampled within each tower footprint.

\section{Results}

\section{Long-term net ecosystem exchange, 2008 -2015}

Both the wet sedge and heath tundra were $\mathrm{CO}_{2}$ sources over the eight years, from January 2008- December 2015 (Fig. 2a; $158 \pm 53 \mathrm{~g} \mathrm{C} \mathrm{m}^{-2}$ lost from heath tundra and $668 \pm 83 \mathrm{~g} \mathrm{C} \mathrm{m}^{-2}$ from wet sedge tundra, with uncertainty surrounding the fluxes estimated by bootstrapping, as described in the Methods), due to $\mathrm{CO}_{2}$ loss during the cold seasons. The tussock tundra, measured continuously from Jan. 2013- Dec. 2014, also acted as a source of $\mathrm{CO}_{2}$ during these two years $\left(30 \pm 17 \mathrm{~g} \mathrm{C} \mathrm{m}^{-2}\right)$, with the seasonal patterns of uptake and emissions more closely following that of the heath tundra than the wet sedge tundra (Fig. 3a).

\section{Soil temperature trends}

Concurrent with these releases of $\mathrm{CO}_{2}$, the soils in our study area have warmed at all depths since the beginning of soil temperature measurements in 2006 (Fig. 4a). Notably, soils at $3 \mathrm{~m}$ depth are nearing thaw $\left(0^{\circ} \mathrm{C}\right)$, where they had only previously reached a maximum of $-2^{\circ} \mathrm{C}$ (Fig. 4a). The soils in the active layer at a depth to $0.9 \mathrm{~m}$ are also freezing at a later date in the fall (Fig. 4b). The annual minimum soil temperatures have continued to increase since the beginning of the measurements in 2006 (Fig 4c). In particular, late fall and early winter in 2014 
were marked by extremely high soil temperatures, with the soils to $0.9 \mathrm{~m}$ depth not fully freezing until late December, about 8 weeks later than in the beginning of measurements (Fig. 4b). We did not detect a trend in soil moisture during the time when surface soils to $7 \mathrm{~cm}$ depth were unfrozen in June, July, and August from 2008 to 2015 at either the wet sedge, heath, or tussock tundra sites (Supplementary Fig. 1).

In conjunction with soil warming, there was also a trend in the lengthening of the zero curtain period in the fall (Fig. 4d). The length of this zero curtain period was correlated with losses of NEE in both the wet sedge and heath tundra, with large emissions of $\mathrm{CO}_{2}$ between September - December in years with a long zero curtain period (Fig. 2b). The wet sedge tundra appears to be more sensitive to changes in the length of the zero curtain period, with an estimated loss of $1.34 \mathrm{~g} \mathrm{C} \mathrm{m}^{-2}$ for each day that the zero curtain period increases, compared to the heath tundra with a loss of $0.65 \mathrm{~g} \mathrm{C} \mathrm{m}^{-2}$ for each day that the zero curtain period increases (Fig. 2b).

There has also been a trend towards later soil thaw in the spring (May - June), although this trend is not as strong as the delay in the freeze-up seen in the late fall and early winter (Fig. 4e). While the wet sedge tundra and heath tundra generally show greater loss of $\mathrm{CO}_{2}$ in years with a late spring (Fig. 5), this loss is not as large as that observed in the fall. Furthermore, in the heath and wet sedge tundra, the relation between spring soil thaw and $\mathrm{CO}_{2}$ loss is weaker (Fig. $5 \mathrm{a}, \mathrm{c} ; \mathrm{p}=0.01$ to 0.04 ) than the relation between the length of the zero curtain and $\mathrm{CO}_{2}$ release in the fall and early winter (Fig.1b, p<0.0001). In the tussock tundra, there was not a statistically significant relation between soil thaw and spring $\mathrm{CO}_{2}$ loss (Fig. 5b; $\mathrm{p}=0.4$ ). Consequently, it appears as though increases in soil temperatures in the fall and early winter, and the corresponding length of the zero curtain period (Figs. 2b, 4d), are a key predictor of $\mathrm{CO}_{2}$ release at these sites.

Long-term data from three other borehole sites in northern Alaska show that since 1986 the day of freeze-up is significantly later (Supplementary Figure 2a; slope $=0.90$ to 1.36 days later per year; $\mathrm{p}=0.001$ to $<0.0001$ ). While these sites show a trend towards an earlier day of soil thaw (Supplementary Figure 2b), the trend is weaker (slope $=0.28$ to 0.57 days earlier per year; $\mathrm{p}=0.006$ to 0.03 ).

\section{Summer carbon fluxes}

All three tundra ecosystems were $\mathrm{CO}_{2}$ sinks during the summer, when more uptake of $\mathrm{C}$ via gross primary productivity $(\mathrm{GPP}=\mathrm{NEE}-\mathrm{ER}$; Methods) was found compared to $\mathrm{C}$ respired 
in ecosystem respiration (ER; June - August; Fig. 6). However, the 2008-2015 summer trends in NEE, GPP, and ER differed among the ecosystems. The heath and tussock tundra ecosystems showed significantly ( $\mathrm{p}=0.001)$ greater $\mathrm{C}$ uptake (NEE was more negative) with time (heath: $5.0 \mathrm{~g} \mathrm{C} \mathrm{m}^{-2} \mathrm{yr}^{-1}$, Fig. 7a; tussock: $-6.5 \mathrm{~g} \mathrm{C} \mathrm{m}^{-2} \mathrm{yr}^{-1}$, Fig. 6b), while the wet sedge tundra did not show a clear trend (Fig. 6c). GPP was more significantly negative (i.e., greater productivity) only for tussock tundra (-23.3 $\mathrm{g} \mathrm{C} \mathrm{m}^{-2} \mathrm{yr}^{-1}, \mathrm{p}<0.001$; Fig. 6e). Consequently, it is not likely that at these sites gains in productivity during the growing season will outpace annual increases in respiration.

\section{Soil Carbon}

The wet sedge tundra at our site has greater $\mathrm{C}$ stocks in the annually-thawed active layer than the tussock or heath tundra sites $\left(16.4 \pm 2.4 \mathrm{~kg} \mathrm{~m}^{-2}\right.$ in the wet sedge versus $11.3 \pm 1.0 \mathrm{~kg} \mathrm{~m}^{-2}$ in the tussock and $11.7 \pm 1.9 \mathrm{~kg} \mathrm{~m}^{-2}$ in the heath tundra; Fig. 7). Given the loss of $668 \mathrm{~g} \mathrm{C} \mathrm{m}^{-2}$ in the wet sedge tundra and $154 \mathrm{~g} \mathrm{C} \mathrm{m}^{-2}$ in the heath tundra (Fig. 2a), this translates to approximately $4.1 \%$ of the total active layer soil C stocks $(0.5 \%$ per year) in the wet sedge and $1.4 \%$ of the total active layer $\mathrm{C}$ stocks $(0.2 \%$ per year) in the heath tundra from $2008-2015$.

\section{Methane Fluxes}

Emissions of $\mathrm{CH}_{4}$ generally peaked between July and early August, with smaller emissions observed during late spring, early summer and fall (Fig. 8). Total $\mathrm{CH}_{4}$ emitted across the common measurement period over the four years of collection (July 11 - September 16) was $1399 \pm 222 \mathrm{mg} \mathrm{CH}_{4} \mathrm{~m}^{-2}$ in $2012 ; 1726 \pm 286 \mathrm{mg} \mathrm{CH}_{4} \mathrm{~m}^{-2}$ in $2013 ; 1621 \pm 278 \mathrm{mg} \mathrm{CH}_{4} \mathrm{~m}^{-2}$ in 2014, and $946 \pm 169 \mathrm{mg} \mathrm{CH}_{4}$ in 2015 (Fig. 8). Converting to $\mathrm{CO}_{2}$ equivalents $\left(\mathrm{CO}_{2}\right.$ e; Methods) and adding them to measured NEE resulted in increased emissions of only $190 \mathrm{~g} \mathrm{CO}_{2}$ equivalents $\mathrm{m}^{-2}\left(2,642 \mathrm{~g} \mathrm{CO}_{2} \mathrm{e} \mathrm{m}^{-2}\right.$ taking into account $\mathrm{CH}_{4}+\mathrm{CO}_{2}$ versus $2,452 \mathrm{~g} \mathrm{CO}_{2} \mathrm{e} \mathrm{m}^{-2}$ taking only $\mathrm{CO}_{2}$ into account; Fig. 3b).

\section{Regional scaling}

The vegetated tundra land area of the Alaska Arctic ecoregion extending from the Brooks Range to the Arctic Ocean is approximately $300,000 \mathrm{~km}^{2}$, comprised of various types of heath, shrub, tussock and wet sedge tundra (Table 1). Of this tundra area, the vegetation within the footprints of our eddy covariance towers is generally representative of $42,552 \mathrm{~km}^{2}$ of the heath, $74,716 \mathrm{~km}^{2}$ of the tussock, and $30,027 \mathrm{~km}^{2}$ of the wet sedge tundra, or in total approximately $50 \%$ of the area of tundra in northern Arctic Alaska. By scaling our two years of continuous 
measurements from January 2013 to December 2014 to the three tundra types by area, we estimate a release over the whole of this Alaska Arctic ecoregion of $14.27 \pm 3.84 \mathrm{Tg} \mathrm{C}$ from these three ecosystems during this time, if all of this area responded in the same way as the ecosystems that we measured in this study. In this calculation, the $\mathrm{C}$ release from the wet sedge tundra dominates the carbon signal ( $8.80 \pm 1.17 \mathrm{Tg} \mathrm{C}$ loss over two years). The area of tussock tundra would have to be extended to that of nearly the entire region, to $290,000 \mathrm{~km}^{2}$, to result in the same spatially scaled $\mathrm{CO}_{2}$ emissions as the wet sedge tundra (Table 1).

\section{Discussion}

\section{Overview}

Our study illustrates the importance of measuring long-term arctic tundra carbon fluxes over the full annual cycle. We have captured the release of $\mathrm{CO}_{2}$ from these ecosystems over multiple years, and how they respond to warming soils, particularly during the most recent years (2013 - 2015) of this study. Moreover, we demonstrate the importance of considering different types of tundra ecosystems. Many studies target tussock tundra (e.g., Hicks-Pries et al., 2013; Sistla et al., 2013) since it is the most dominant type of tundra vegetation in northern Alaska. However, here we find that wet sedge tundra, with a relatively smaller area than tussock tundra, can have disproportionate impacts if it responds strongly (Table 1). Below, we further discuss our findings in the context of other studies of tundra $\mathrm{C}$ fluxes and soil carbon, warming soil temperatures in northern Alaska.

\section{Net ecosystem exchange and soil carbon loss}

We are aware of only a few published studies of year-round arctic tundra eddy covariance measurements of NEE (Oechel et al., 2014; Lüers et al., 2016), while other NEE eddy coviarance measurements take into account a subset of the winter months in alpine, subarctic tundra (e.g., Webb et al., 2016). Over one year of full annual measurements of Alaskan tussock tundra Oechel et al. (2014) find a source of $13.6 \mathrm{~g} \mathrm{C} \mathrm{m}^{-2} \mathrm{yr}^{-1}$, which agrees well with the two full annual measurements of tussock tundra NEE we present here, estimated as a source of $15 \mathrm{~g} \mathrm{C} \mathrm{m}^{-2} \mathrm{yr}^{-1}$ in 2013 and $7 \mathrm{~g} \mathrm{C} \mathrm{m}^{-2} \mathrm{yr}^{-1}$ (Fig. 3a). Annual NEE over a full year at a high arctic site on Svalbard is measured at $0 \mathrm{~g} \mathrm{C} \mathrm{m}^{-2} \mathrm{yr}^{-1}$ at a site with low productivity and only moderate emissions in the winter, possibly due to little carbon stock available for microbial decomposition (Lüers et al., 
2016). Luers et al. (2016) also note that nearly two-thirds of growing season $\mathrm{CO}_{2}$ uptake is compensated by these moderate winter emissions. Webb et al. (2016) report a large source of $\mathrm{CO}_{2}$ based on eddy covariance NEE measurements in subarctic tussock tundra, $130 \mathrm{~g} \mathrm{C} \mathrm{m}^{-2} \mathrm{yr}^{-1}$, with the overall conclusion that subarctic and arctic tundra is shifting from an overall $\mathrm{C}$ sink to a C source. Out of 1,400 years of flux site measurements across terrestrial ecosystems worldwide, the mean annual flux of NEE is a sink of $-156 \pm 284 \mathrm{~g} \mathrm{C} \mathrm{m}^{-2} \mathrm{yr}^{-1}$, with the greatest sinks generally found in evergreen plantation forests, and the sources associated with disturbed sites (Baldocchi, 2014). The $\mathrm{CO}_{2}$ release from the undisturbed, intact tundra ecosystems presented here is similar to that found in boreal forests in the first 10 years following disturbance, which range from a loss of $\sim 20-200 \mathrm{~g} \mathrm{C} \mathrm{m}^{-2} \mathrm{yr}^{-1}$ (Amiro et al., 2010). Overall, our results agree with the conclusion of Webb et al. (2016) that the arctic is shifting or has shifted to a source of C.

However, a key question is whether these annual increases (net losses to the atmosphere) in NEE in the wet sedge and heath tundra will be sustained over the longer-term. The warm borehole temperatures suggest that permafrost thaw may have begun, thereby promoting decomposition of labile soil $\mathrm{C}$ in the active layer and releasing $\mathrm{CO}_{2}$ to the atmosphere, at the wet sedge tundra in particular. The rate of loss of soil $\mathrm{C}$ we find here would be difficult to sustain over decades if this $\mathrm{C}$ is simply coming from increased turnover of SOM in the current active layer, including surface litter $\mathrm{C}$ losses, or increased root respiration under warmer conditions. However, it is possible that as the active layer continues to deepen with permafrost thaw, more SOM is becoming available for decomposition (Hicks Pries et al., 2013). The dynamics of C deeper in the soil than the current active layer are unknown at these sites, although research suggests that these deeper C stores can be large (Hugelius et al. 2014), and that these deeper stores may be attributed to releases of older soil C (Hicks-Pries et al., 2013). Decomposition of added SOM due to thawing permafrost deeper than the current active layer would likely continue to result in increases in respiration that are greater than any increases in productivity, unless there are extreme shifts in plant community composition to much larger growth forms, such as shrubs or trees (e.g., Myers-Smith et al., 2015). While we have documented increases in shrub abundance and biomass in this watershed, encompassing shrubs in the heath, tussock, and wet sedge tundra sites, since the 1980s (Bret-Harte et al., unpublished data), it does not appear as though increases in productivity associated with this growth have compensated for soil $\mathrm{C}$ release (e.g., Fig. 5). However, it is possible that the soil C losses we detected may have been even 
greater without these documented increases in shrub biomass. Furthermore, it is important to note that much of the soil warming occurred during the fall and winter months (Fig.4b, c, d) and in conjunction with recent losses of late summer and early fall sea ice, particularly that off the coast of northern Alaska (Parmentier et al., 2013). This fall and winter soil temperature warming followed plant senescence, which thereby precluded additional plant uptake of $\mathrm{CO}_{2}$, but enhanced $\mathrm{CO}_{2}$ respiratory losses.

\section{Methane Fluxes}

The wet sedge tundra is the site where we would expect to see the greatest $\mathrm{CH}_{4}$ release given the saturated soil conditions and presence of sedges with aerenchyma, or gas conducting tissues (von Fischer et al., 2010), but nevertheless, the emissions over our four growing seasons of measurements were low (Fig 3b, Fig. 8). While recent work suggests that wintertime fluxes of arctic tundra $\mathrm{CH}_{4}$ flux can be significant (Zona et al., 2016), we observed declining fluxes by mid to late September or October (Fig. 8). However, during the period of measurement from July 11 - September 16 across our four years of $\mathrm{CH}_{4}$ measurements (e.g, the 'common period' and when the flux rates were generally greatest, Fig. 8) the mean total emission $\left(1.4 \pm 0.3 \mathrm{~g} \mathrm{CH}_{4} \mathrm{~m}^{-}\right.$

${ }^{2}$ ), was slightly less than that reported across five sites in Zona et al. (2016) during the cold season $\left(1.7 \pm 0.2 \mathrm{~g} \mathrm{CH}_{4} \mathrm{~m}^{-2}\right)$. Extensions of the measurement systems here to other wetland tundra sites in this region would help to clarify the amount and heterogeneity of $\mathrm{CH}_{4}$ emissions. Further, it would be interesting to determine if the $\mathrm{CH}_{4}$ from this wet sedge tundra site is being oxidized and then released as $\mathrm{CO}_{2}$.

\section{Soil Temperatures}

Other borehole monitoring stations on the Alaskan North Slope and in other parts of the Arctic have shown similar warming trends, particularly in the fall and early winter (Osterkamp, 2005; Osterkamp \& Jorgenson, 2006; Romanovsky et al., 2010). For example, Osterkamp (2005) finds that across a transect over the Alaskan Arctic, sites on the Arctic Coastal Plain have shown warming of 3 to $4^{\circ} \mathrm{C}$, while those of the Brooks Range, including its northern and southern foothills, the warming was 1 to $2^{\circ} \mathrm{C}$. Osterkamp \& Jorgenson (2006) predict that the discontinuous permafrost boundary could extend north of the Brooks Range in the coming decades, if not sooner. These studies indicate that since the warming is not restricted to our site, increased amounts of $\mathrm{CO}_{2}$ could be released across a wider geographic area than we are currently measuring. 


\section{Conclusions}

Our results suggest that warmer autumn and winter periods are already leading to substantial release of $\mathrm{C}$ from undisturbed, intact tundra permafrost ecosystems in northern Alaska. Further, they suggest that wet sedge ecosystems may contribute disproportionately to $\mathrm{C}$ loss. Our data illustrate the importance of measuring $\mathrm{C}$ fluxes over the full annual cycle across numerous years and representative types of tundra. They also illustrate the need to extend these types of long-term measurements in a coordinated manner using similar types of instrumentation, and effectively transfer this information into biogeochemical modeling frameworks.

Given the large amounts of C stored in permafrost soils worldwide (Hugelius et al., 2014) and research suggesting that $\mathrm{C}$ stores in these soils may be more vulnerable to climate warming due to 'enhancing' microbial responses to temperature change (Karhu et al., 2014), there is the potential for a strong positive feedback to global climate warming from arctic terrestrial ecosystems. With the continued increases in greenhouse gas emissions worldwide, and the current trend towards increased Arctic temperatures in fall and winter (Jeffries et al., 2013), it is likely that elevated $\mathrm{CO}_{2}$ emissions from these ecosystems will continue. These ecosystems may be on a new trajectory of $\mathrm{CO}_{2}$ release, which could cause an enhanced positive feedback to climate warming, if our results are representative of larger areas of the Arctic.

\section{Acknowledgements}

This work was funded by the National Science Foundation Division of Polar Programs Arctic Observatory Network grant numbers 856864, 1304271, 0632264, and 1107892. This study was also partially funded by the NSF Alaska Experimental Program to Stimulate Competitive Research award number OIA-1208927. Logistical support was provided by CH2M Hill Polar Services. We thank Diane Huebner, Jackson Drew, and Lola Oliver for assistance with soil C samples. F.S. Chapin III, S.C. Wofsy, and two anonymous reviewers provided valuable comments on an earlier draft of this manuscript.

\section{References}

Amiro BD et al. 2010. Ecosystem carbon dioxide fluxes after disturbance in forests of North America. Journal of Geophysical Research - Biogeosciences 115 (G4):

doi:10.1029/2010JG001390. 
Baldocchi D. 2014. Measuring fluxes of trace gases and energy between ecosystems and the atmosphere- the state and future of the eddy covariance method. Global Change Biology 20: $3600-3609$.

Belshe EF, Schuur EAG, Bolker BM. 2013. Tundra ecosystems observed to be $\mathrm{CO}_{2}$ sources due to differential amplification of the carbon cycle. Ecology Letters 16 (10): 1307 -1315.

Björkman MP et al. 2010. Winter carbon dioxide effluxes from Arctic ecosystems: An overview and comparison of methodologies. Global Biogeochemical Cycles 24(GB3010): $1-10$.

Burba GG, et al. 2008. Addressing the influence of instrument surface heat exchange on the measurements of $\mathrm{CO} 2$ flux from open-path gas analyzers. Global Change Biology 14: 1854-1876.

Burba GG, Anderson DA. 2010. Brief Practical Guide to Eddy Covariance Flux Measurements: Principles and Workflow Examples for Scientific and Industrial Applications. (LI-COR, Lincoln, Nebraska, USA).

Chang Y-W et al. 2104. Methane emissions from Alaska in 2012 from CARVE airborne observations. Proceedings of the National Academy of Sciences USA 111: 16694-16699.

Christensen TR. 2014. Understand Arctic methane variability. Nature 509: 279-281.

Coyne PI, Kelley JJ. 1971. Release of carbon dioxide from frozen soil to the Arctic atmosphere. Nature 234: 407-408.

Dlugokencky E, et al. 2009. Observational constraints on recent increases in the atmospheric $\mathrm{CH}_{4}$ burden. Geophysical Reseach Letters 36: L18803.

Drotz SH, Sparrman T, Nilsson MB, Schleucher J, Öquist MG. 2010. Both catabolic and anabolic heterotropic microbial activity proceed in frozen soils Proceedings of the National Academy of Sciences USA 107: 21046 - 21051.

Duarte CM, Lenton TM, Wadhams P, Wassman P. 2012. Abrupt climate change in the Arctic. Nature Climate Change 2: 60 - 62.

Efron B, Tibshirani R. 1998. An Introduction to the Bootstrap. (Chapman and Hall, Boca Raton)

Euskirchen ES, Bret-Harte MS, Scott GJ, Edgar C, Shaver GR. 2012. Seasonal patterns of carbon dioxide and water fluxes in three representative tundra ecosystems in northern Alaska. Ecosphere 3: 1-19. 
Falge E, et al. 2001. Gap filling strategies for defensible annual sums of net ecosystem exchange. Agricultural and Forest Meteorology 107: 43-69.

Fisher J.B, et al. 2014. Carbon cycle uncertainty in the Alaskan Arctic. Biogeosciences 11: 4271-4288.

Fratini G, Mauder M. 2014. Towards a consistent eddy covariance processing: an intercomparison of EddyPro and TK3. Atmosphere Measurement Techniques 7: 22633381.

Hicks Pries CE, Schuur EAG, Crummer KG. 2013. Thawing permafrost increases old soil and autotrophic respiration in tundra: Partitioning ecosystem respiration using $\delta^{13} \mathrm{C}$ and $\Delta^{14} \mathrm{C}$. Global Change Biology 19: 649 - 661.

Hinzman LD, Kane DL, Gieck RE, Everett KR. 1991. Hydrologic and thermal properties of the active layer in the Alaskan Arctic. Cold Regions Science and Technology 19: 95-110.

Hugelius G. et al. 2014. Estimated stocks of circumpolar permafrost carbon with quantified uncertainty ranges and identified data gaps. Biogeosciences 11: 6573-6593.

Jeffries MO, Overland JE, Perovich DK. 2013. The Arctic shifts to a new normal. Physics Today 66: 35-40.

Jorgenson MT, Heiner M. 2004. Ecosystems of Northern Alaska. ABR, Inc. and The Nature Conservancy, Anchorage, AK.

Kade A, Bret-Harte MS, Euskirchen ES, Edgar C, Fulweber R. 2012. Seasonal variations in $\mathrm{CO}_{2}$ flux among various tundra plant communities in Arctic Alaska. J Geophys Res Biogeosciences 117: 1-11.

Karhu K et al. 2014. Temperature sensitivity of soil respiration rates enhanced by microbial community response Nature 513: 81 -84.

LI-COR Inc. 2004. LI-7500 $\mathrm{CO}_{2} / \mathrm{H}_{2} \mathrm{O}$ Analyzer Instruction Manual (LI-COR, Lincoln, Nebraska, USA)

LI-COR Inc. 2009. LI-7500A Open-path $\mathrm{CO}_{2} / \mathrm{H}_{2} \mathrm{O}$ Open Path Gas Analyzer Instruction Manual (LI-COR, Lincoln, Nebraska, USA)

LI-COR Inc. 2010a. LI-7200 $\mathrm{CO}_{2} / \mathrm{H}_{2} \mathrm{O}$ Analyzer Instruction Manual, LI-COR (Lincoln, Nebraska, USA)

LI-COR Inc. 2010b. LI-7700 Open Path $\mathrm{CH}_{4}$ Analyzer Instruction Manual. (LI-COR, Lincoln, Nebraska, USA). 
LI-COR Inc. 2013. EddyPro® 4.2 Help and User's Guide. (LI-COR, Inc. Lincoln, Nebraska, USA)

Lüers J, Westermann S, Piel K, Boike J. 2014. Annual CO2 budget and seasonal CO2 exchange signals at a high Arctic permafrost site on Spitsbergen, Svalbard archipelago.

Biogeosciences 11: 6307- 6322.

Massman WJ. 2000. A simple method for estimating frequency response corrections for eddy covariance systems. Agricultural and Forest Meteorology 104(3): 185-198.

Massman WJ. 2001. Reply to comment by Rannik on "A simple method for estimating frequency response corrections for eddy covariance systems" Agricultural and Forest Meteorology 107: 247-251.

McGuire AD, et al. 2009. Sensitivity of the carbon cycle in the Arctic to climate change. Ecological Monographs 79:523-555.

McGuire AD, et al. 2012. An assessment of the carbon balance of the Arctic tundra: comparisons among observations, process models, and atmospheric inversions. Biogeosciences 9: 3185-3204.

Mueller CW et al. 2015. Large amounts of labile organic carbon in permafrost soils of Northern Alaska. Global Change Biology 21: 2804 - 2817.

Myers-Smith IH. 2015. Climate sensitivity of shrub growth across the tundra biome. Nature Climate Change 5: 887 - 891.

Myhre GD, et al. 2013. Anthropogenic and Natural Radiative Forcing. In: Climate Change 2013: The Physical Science Basis. Contribution of Working Group I to the Fifth Assessment Report of the Intergovernmental Panel on Climate Change [Stocker TF, et al. (eds.)]. Cambridge University Press, Cambridge, United Kingdom and New York, NY, USA.

Natali SM, Schuur EAG, Rubin RL. 2012. Increased plant productivity in Alaskan tundra as a result of experimental warming of soil and permafrost. Journal of Ecology 100: 488-498.

Nauta AL, et al. 2015. Permafrost collapse after shrub removal shifts tundra ecosystems to a methane source. Nature Climate Change 5: 67 -70.

O'Conner FM, et al. 2010. Possible role of wetlands, permafrost, and methane hydrates in the methane cycle under future climate change: A review. Reviews of Geophysics 48 (RG4005): 1-33, doi: 10.1029/2010RG000326. 
Oechel WC, Laskowski CA, Burba G, Gioli B, Kalhori AAM. 2014. Annual patterns and budget of $\mathrm{CO}_{2}$ flux in an Arctic tussock tundra ecosystem. Journal of Geophysical Research Biogeosciences 119: 323-339, doi:10.1002/2013JG002431.

Osterkamp TE. 2005. The recent warming of permafrost in Alaska. Global and Planetary Change 49: 187-202.

Osterkamp TE, Jorgenson JC. 2006. Warming permafrost in the Arctic National Wildlife Refuge, Alaska. Permafrost and Periglacial Processes 17: 65 - 69.

Overland JE, Wang M, Walsh JE, Stroeve JC. 2013. Future Arctic climate changes: Adaptation and mitigation time scales. Earth's Future 2: 68-74.

Panikov NS, Flanagan PW, Oechel WC, Matepanov MA, \& Christensen TR. 2006 Microbial activity in soils frozen to below $-39^{\circ} \mathrm{C}$. Soil Biology and Biogeochemistry 38: 785 - 794 .

Papale D, et al. 2006. Towards a standardized processing of net ecosystem exchange measured with eddy covariance technique: Algorithms and uncertainty estimation. Biogeosciences 3: $571-583$.

Parmentier F-J W, et al 2013 The impact of lower sea-ice extent on Arctic greenhouse-gas exchange. Nature Climate Change 3: 195 -202.

Reichstein M, et al.2005. On the separation of net ecosystem exchange into assimilation and ecosystem respiration: Review and improved algorithm. Global Change Biology 11: 14241439.

Romanovsky VE, Sergueev DO \& Osterkamp TE 2003. Temporal variations in the active layer and near-surface permafrost temperatures at the long-term observatories in Northern Alaska. In: Permafrost, Phillips, M., Springman, S. \& Arenson, L.U. (eds), Swets \& Zeitlinger, Lisse, pp. 989-994.

Romanovsky VE, Smith SL, Christiansen HH. 2010. Permafrost thermal state in the polar Northern Hemisphere during the international polar year 2007-2009: a synthesis. Permafrost and Periglacial Processes 21: 106-116.

Schuur EAG, et al. 2015. Climate change and the permafrost carbon feedback. Nature 520: 171-179.

Sen PK. 1968. Estimates of the Regression Coefficient Based on Kendall's Tau. Journal of the American Statistical Association 63: 1379-1389. 
Shaver GR, Chapin FS III. 1991. Production: Biomass relationships and element cycling in contrasting arctic vegetation. Ecological Monographs 61(1): 1-31.

Sistla SA, et al. 2013. Long-term warming restructures Arctic tundra without changing net carbon storage. Nature 497: 615 - 618 .

Ueyama M, et al. 2013. Seasonal and spatial variations of carbon fluxes of arctic and boreal ecosystems in Alaska. Ecological Applications 23: 1798 - 1816.

von Fischer JC, Rhew RC, Ames GM, Fosdick BK, von Fischer PE. 2010. Vegetation height and other controls of spatial variability in methane emissions from the Arctic coastal tundra at Barrow. Alaska, Journal of Geophysical Research - Biogeosciences 115: doi: 10.1029/2009JG001283.

Webb EE et al. 2016. Increased wintertime $\mathrm{CO}_{2}$ loss as a result of sustained tundra warming. Journal of Geophysical Research - Biogeosciences, 121, doi: 10.1002/2014JG002795.

Webb EK, Pearman GI, Leuning R. 1980. Correction of flux measurements for density effects due to heat and water vapour transfer. Quarterly Journal of the Royal Meteorological Society 106: 85-100.

Yue S, Pilon P, Phinney B, Cavadias G. 2002. The influence of autocorrelation on the abilityto detect trend in hydrological series. Hydrological Processes 16: 1807-1829.

Zona D et al. 2016. Cold season emissions dominate the Arctic tundra methane budget. Proceedings of the National Academy of Sciences USA 113: 40-45. 
Table 1. $\mathrm{CO}_{2}$ exchange budget across heath, tussock and wet sedge tundra ecosystems of arctic Alaska based on data collected from January 2013- December 2014. The \pm error is determined by bootstrapping (Methods) and is also area-weighted.

\begin{tabular}{llll}
\hline Vegetation type & $\begin{array}{l}\text { Area } \\
\left(\mathrm{km}^{2}\right)\end{array}$ & $\begin{array}{l}\text { Total NEE } \\
\left(\mathrm{g} \mathrm{C} \mathrm{m}^{-2}\right)\end{array}$ & $\begin{array}{l}\text { Spatially scaled NEE } \\
(\mathrm{Tg} \mathrm{C})\end{array}$ \\
\hline Heath tundra & 42,552 & $75 \pm 33$ & $3.20 \pm 1.4$ \\
Tussock tundra* & 74,716 & $30 \pm 17$ & $2.27 \pm 1.27$ \\
Wet sedge tundra** & 30,027 & $293 \pm 39$ & $8.80 \pm 1.17$ \\
Total of all three & 147,295 & $399 \pm 97$ & $14.27 \pm 3.84$ \\
\hline
\end{tabular}

* The areal extent of tussock tundra, under current conditions, would have to increase by a factor of 3.88 (to $290,000 \mathrm{~km}^{2}$ ) to match the NEE of the wet sedge tundra.

** Note that the wet sedge tundra included in the area here excludes wet sedge of the Coastal Plain, which is assumed to be functionally different than the inland wet sedge tundra (Methods). 
Table 2. Periods of data loss $>1$ week at the heath, tussock, and wet sedge tundra sites from January 1, 2008 - December 31, 2014. Data loss during these periods was due to either power outages or instrument maintenance and malfunction.

\begin{tabular}{c|c}
\hline $\begin{array}{c}\text { Site (Type of } \\
\text { Analyzer) }\end{array}$ & Periods of data loss (month/day/year) \\
\hline & $2 / 5 / 2008-2 / 27 / 2008,9 / 20 / 2008-10 / 15 / 2008,1 / 2 / 2009-3 / 10 / 2009$, \\
Heath (LI-7500) & $8 / 24 / 2010-9 / 1 / 2010,10 / 10 / 2011-10 / 17 / 2011,1 / 18 / 2012-1 / 30 / 2012$, \\
& $11 / 15 / 2012-12 / 3 / 2012,9 / 15 / 2013-9 / 26 / 2013$ \\
\hline Heath (LI-7200) & $9 / 14 / 2013-9 / 25 / 2013,10 / 10 / 2013-12 / 1 / 2013,5 / 3 / 2014-6 / 7 / 2014$, \\
& $9 / 27 / 2014-10 / 10 / 2014$ \\
\hline & $1 / 1 / 2008-5 / 17 / 2008,10 / 5 / 2008-12 / 31 / 2008,1 / 1 / 2009-4 / 8 / 2009$, \\
Tussock (LI-7500) & $9 / 17 / 2009-12 / 31 / 2009,1 / 1 / 2010-5 / 14 / 2010,10 / 3 / 2010-12 / 31 / 2010$, \\
& $1 / 1 / 2011-3 / 2 / 2011,10 / 26 / 2011-12 / 31 / 2011,1 / 1 / 2012-3 / 19 / 2012$ \\
\hline & $2 / 28 / 2008-3 / 9 / 2008,5 / 12 / 2008-5 / 30 / 2008,11 / 29 / 2008-12 / 12 / 2008$, \\
Wet Sedge (LI-7500 & $12 / 24 / 2008-2 / 27 / 2009,10 / 15 / 2009-11 / 5 / 2009,12 / 23 / 2010-$ \\
or LI-7500A) & $1 / 20 / 2011,2 / 11 / 2011-2 / 26 / 2011,9 / 3 / 2012-9 / 13 / 2012,12 / 2 / 2012-$ \\
& $2 / 15 / 2012$ \\
\hline
\end{tabular}




\section{Figures}

Figure 1. Monthly mean daily NEE $\left(\mu \mathrm{mol} \mathrm{CO} \mathrm{m}^{-2} \mathrm{~s}^{-1}\right)$ in 2013 and 2014 at the heath tundra site based on common half-hourly data collected with the LI-7500 and LI-7200 analyzers, including LI-7500 data adjusted for sensor heating and not adjusted for sensor heating (a). Error bars represent the standard deviation of the mean. In (b), a comparison between LI-7500 half-hourly $\operatorname{NEE}\left(\mu \mathrm{mol} \mathrm{CO} \mathrm{Cm}^{-2} \mathrm{~s}^{-1}\right)$ adjusted for sensor heating and not adjusted for sensor heating.

Figure 2. Cumulative net ecosystem exchange (NEE g C m${ }^{-2}$ ) between January 1, 2008 to December 31, 2014 for the wet sedge and heath tundra (a). Inset (b): Cumulative NEE between September - December for the wet sedge and heath tundra versus the duration of the zero curtain period during each measurement year.

Figure 3. Cumulative NEE between January 1, 2013 - December 31, 2014 for the wet sedge, heath, and tussock tundra, corresponding to the common period of full annual measurements across the three ecosystems (a). Cumulative emissions of $\mathrm{CO}_{2}$ from both $\mathrm{NEE}$ and $\mathrm{NEE}+\mathrm{CH}_{4}$, expressed as $\mathrm{CO}_{2}$ equivalents $\left(\mathrm{CO}_{2} \mathrm{e}\right)$ for the wet sedge tundra (b).

Figure 4. In (a), time series of soil temperature from September 2006 - March 2015 from the borehole monitoring station at Imnavait. Depths are from $0.34 \mathrm{~m}$ to $10 \mathrm{~m}$. Based on the time series in (a), we show the day of complete soil freeze in the fall (b), the annual minimum soil temperature (c), the duration of the zero curtain period (d), and the day of thaw (e). Error bars represent the standard deviation based on computing the mean across soil temperatures recorded at depths to $0.9 \mathrm{~m}$, as described in the Methods. The slope of the line is based on the Theil-Sen estimate and the significance is assessed using a Mann-Kendall test, also described in the Methods. There is no trend line shown in the day of thaw (e) since there was not a statistically significant trend.

Figure 5. Day of soil thaw versus total May-June net ecosystem exchange (NEE, $\mathrm{g} \mathrm{C} \mathrm{m}^{-2}$ ) at the heath (a), tussock (b), and wet sedge tundra. Each point for soil thaw represents the mean and standard deviation across depths of $0.32 \mathrm{~m}, 0.50 \mathrm{~m}$ and 0.90 for the day after which soil temperature measurements remained above $0.1^{\circ} \mathrm{C}$. The NEE error bars represent standard error 
based on bootstrapping, as described in the Methods. There is no trend line shown in the tussock tundra (b) since there was not a statistically significant trend.

Figure 6. Trends in total growing season (June, July, and August) net ecosystem exchange (NEE, $\mathrm{g} \mathrm{C} \mathrm{m}^{-2}$ ), gross primary productivity (GPP, $\mathrm{g} \mathrm{C} \mathrm{m}^{-2}$ ), and ecosystem respiration (ER, g C $\mathrm{m}^{-2}$ ) from $2008-2015$ for the wet sedge, heath, and tussock tundra. Theil-Sen trend lines are only shown for significant trends $(\mathrm{p} \leq 0.001)$ based on Mann-Kendall test, with the trend analysis described in the Methods. The error bars represent standard error based on bootstrapping, also described in the Methods.

Figure 7. Soil $\mathrm{C}$ in the active layer for the wet sedge, tussock, and heath tundra (mean \pm standard error).

Figure 8. Total daily methane $\left(\mathrm{CH}_{4}\right)$ flux in the wet sedge tundra from $2012-2015$. The vertical lines indicate the beginning and end of the 'common measurement period' over the four years of data collection (July 11 - September 16). The error bars represent daily standard error based on bootstrapping, as described in the Methods. 


\section{Long-term release of carbon dioxide from arctic tundra ecosystems in Alaska Euskirchen et al.}

\section{Supplemental Figures}

Supplementary Figure 1. Mean daily soil moisture $(7 \mathrm{~cm}$ depth) at the heath, tussock and wet sedge tundra sites during the summer months, averaged over June, July, and August during the periods when soils were unfrozen.

Supplementary Figure 2. Day complete freeze up (a) and soil thaw (b) of the active layer at other borehole monitoring sites on the North Slope, including Deadhorse $\left(70.1613^{\circ} \mathrm{N},-148.4653^{\circ} \mathrm{W}\right)$, Franklin Bluffs $\left(69.6739^{\circ} \mathrm{N},-148.7219^{\circ} \mathrm{W}\right)$, and West Dock $\left(70.3745^{\circ} \mathrm{N},-148.5522^{\circ} \mathrm{W}\right)$, with the data record beginning in 1986. At Deadhorse, complete freeze-up did not occur until January 2 in 2012 (indicated as day-of-year 367), and January 14 in 2013 (indicated as day-of-year 379). Data are updated from Romanovsky et al. (2003). The slope of the line is based on the Theil-Sen estimate and the significance is assessed using a Mann-Kendall test, described in the Methods. 

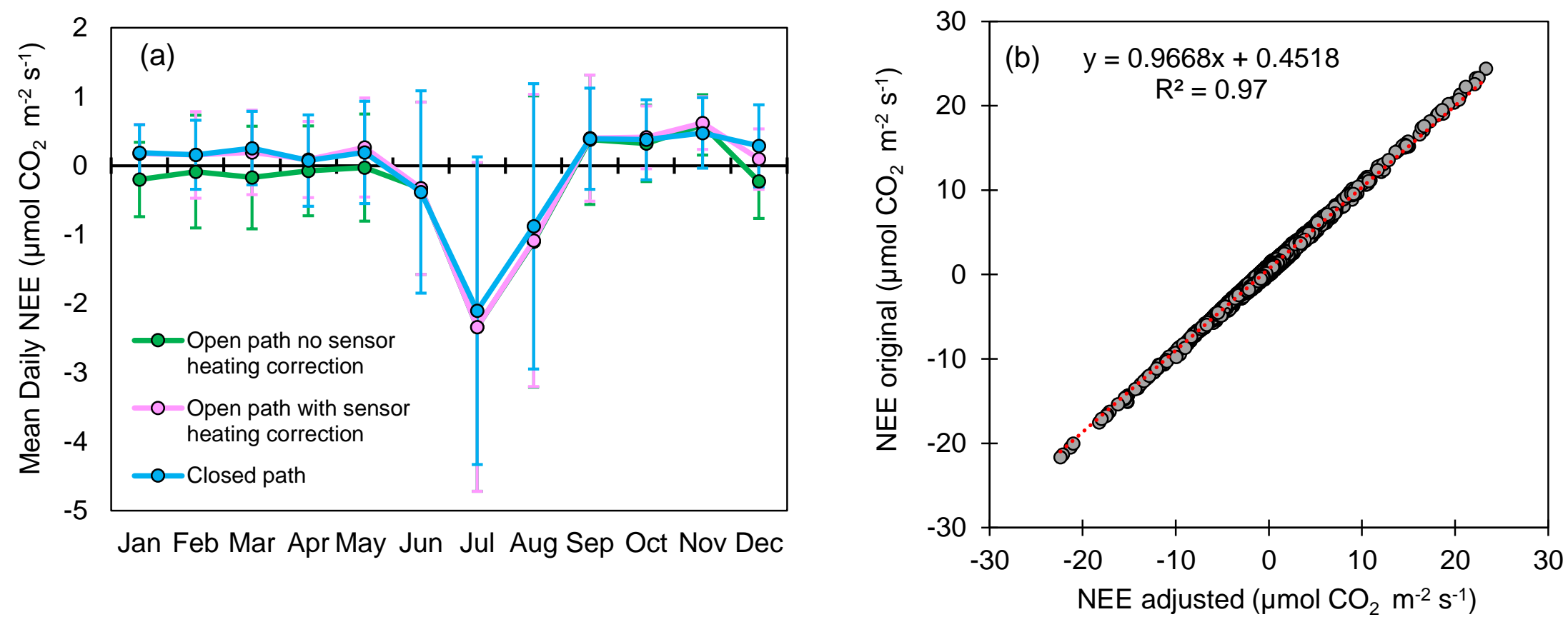
Figure 2

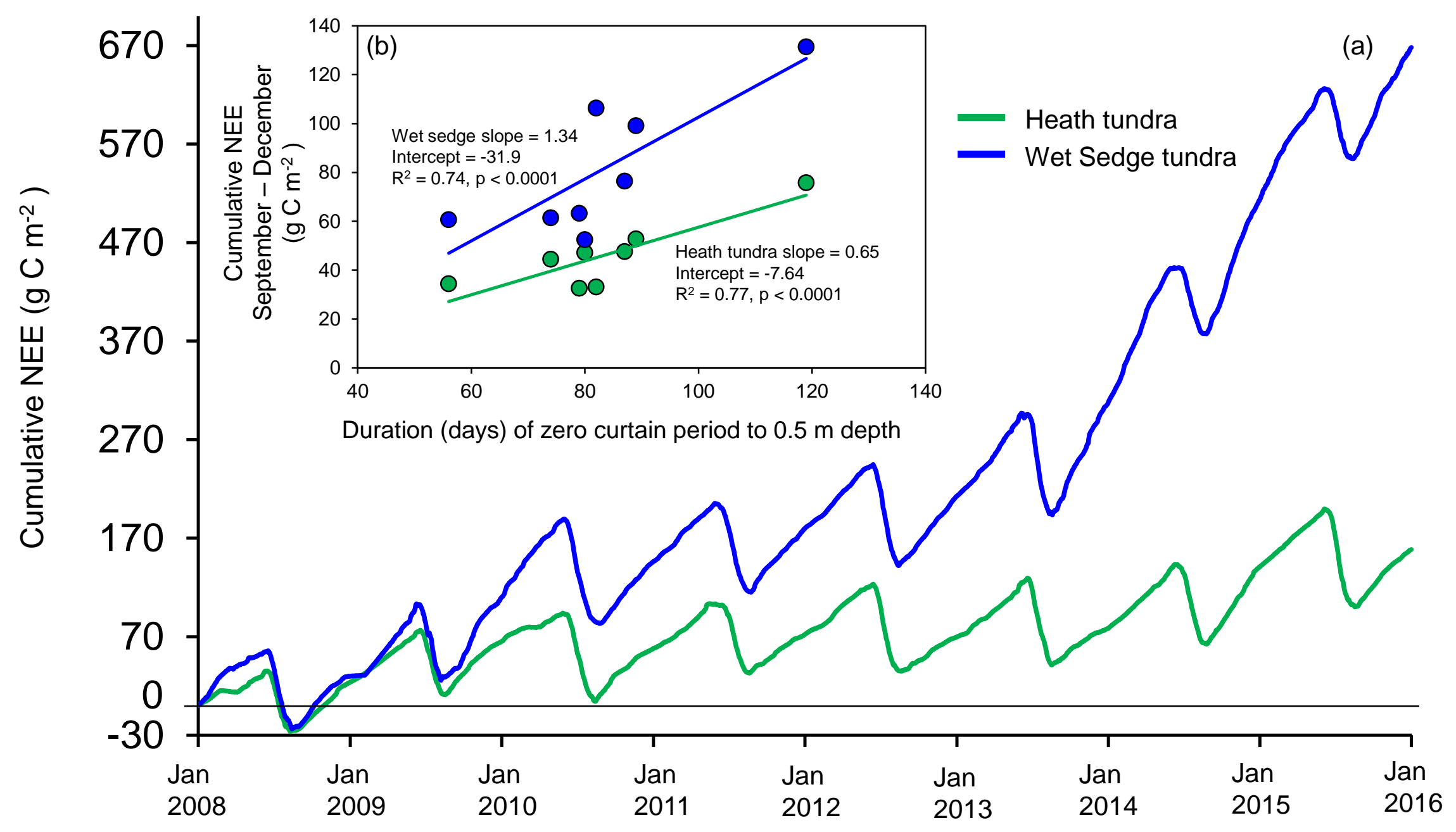



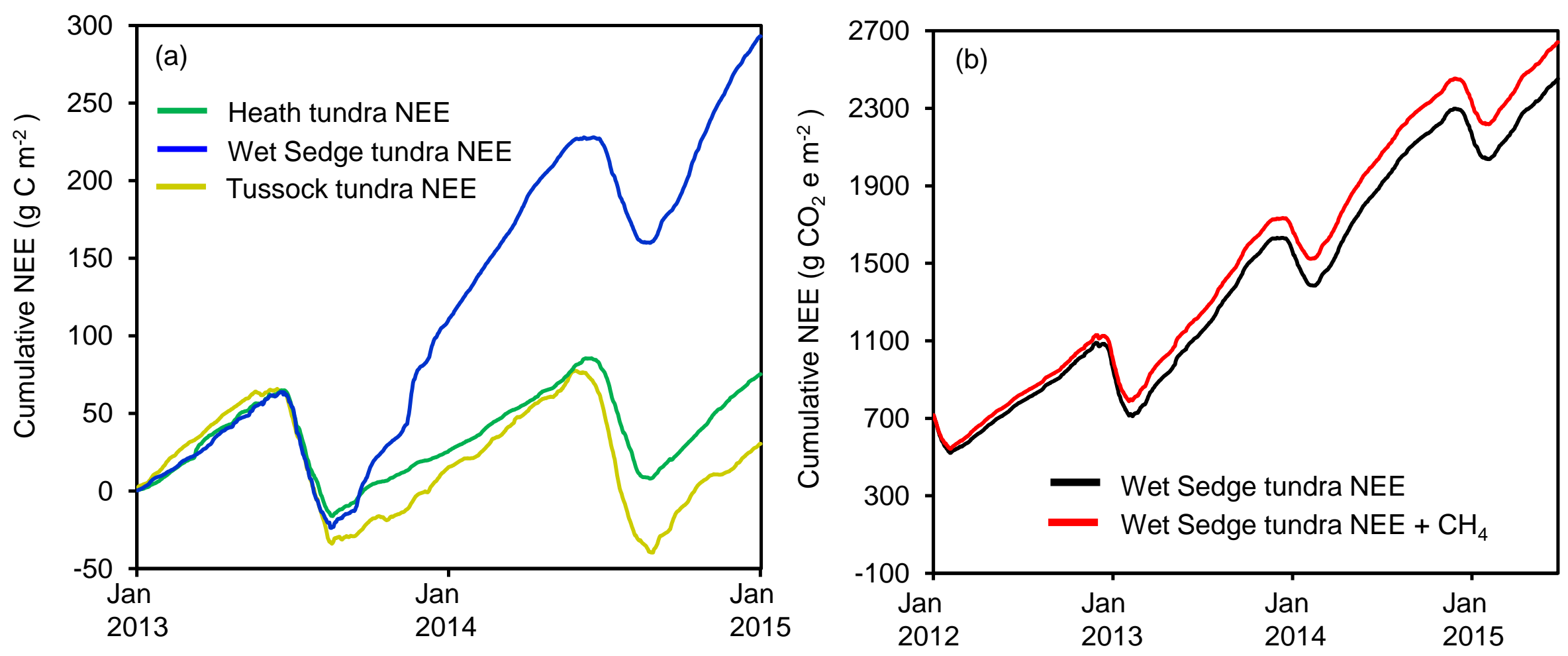


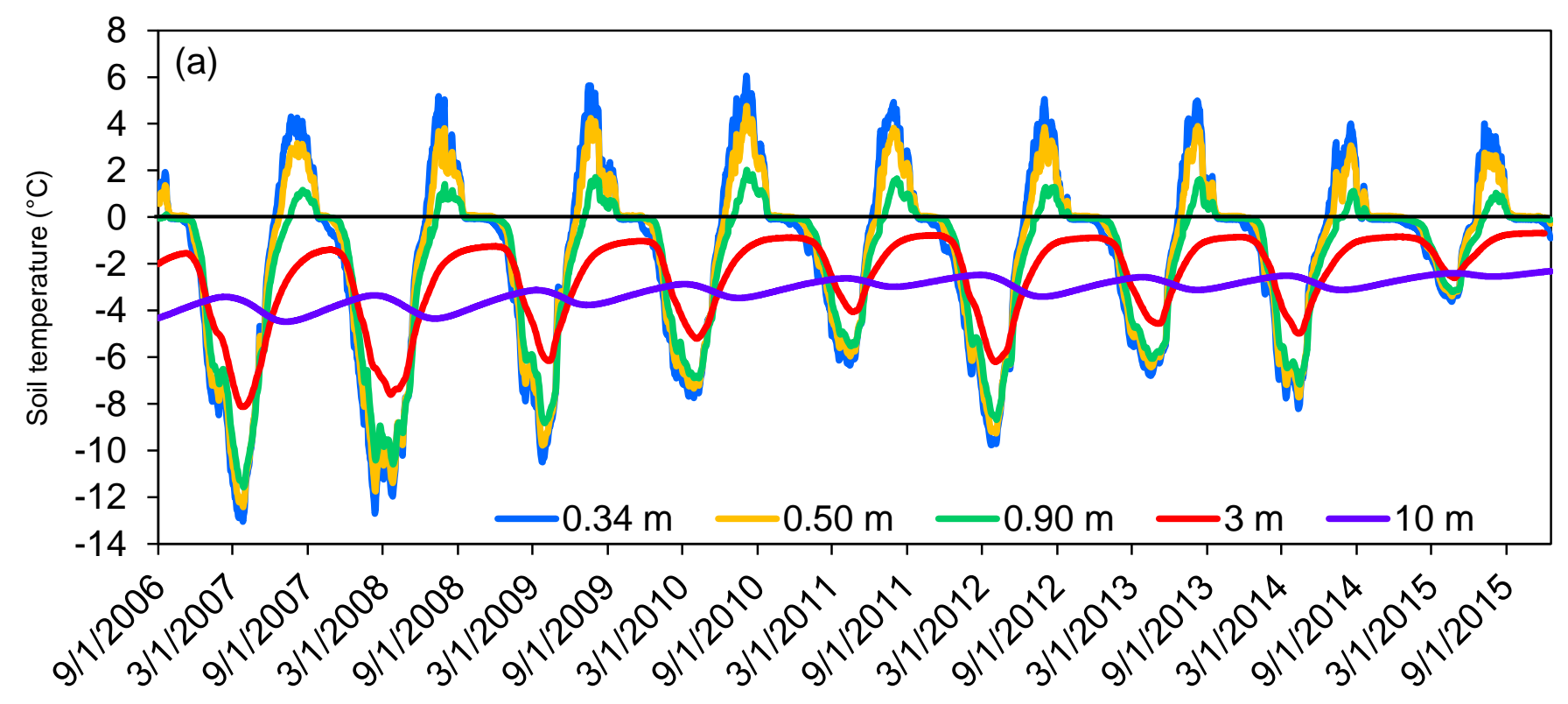

Figure 4
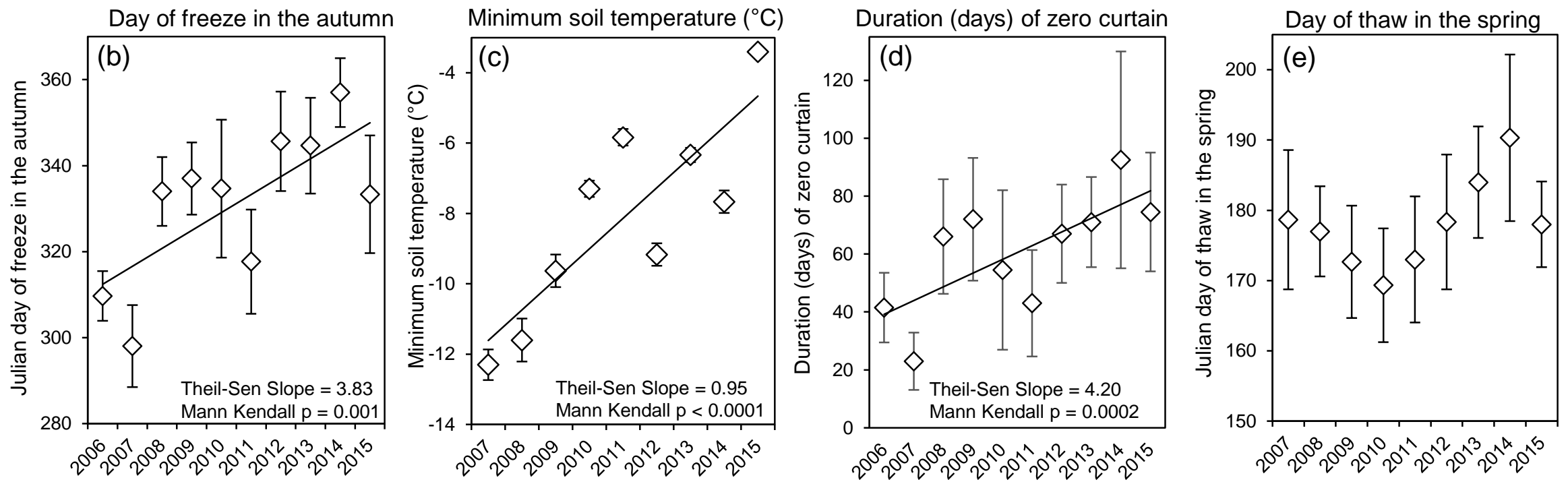


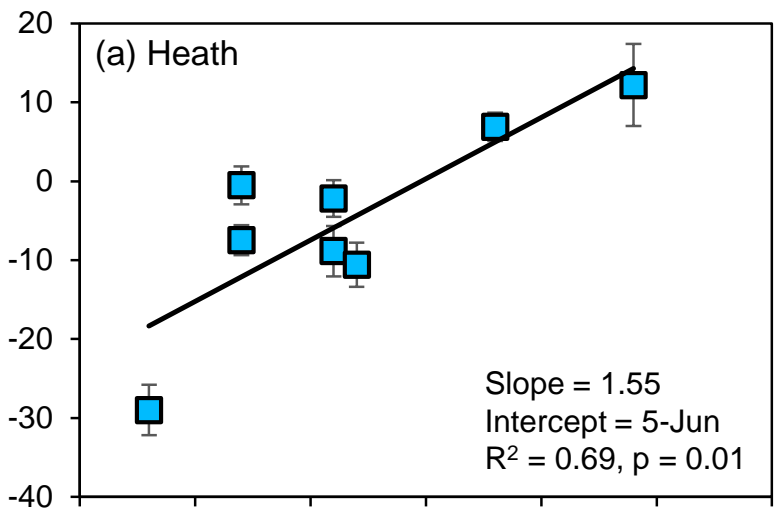

Figure 5
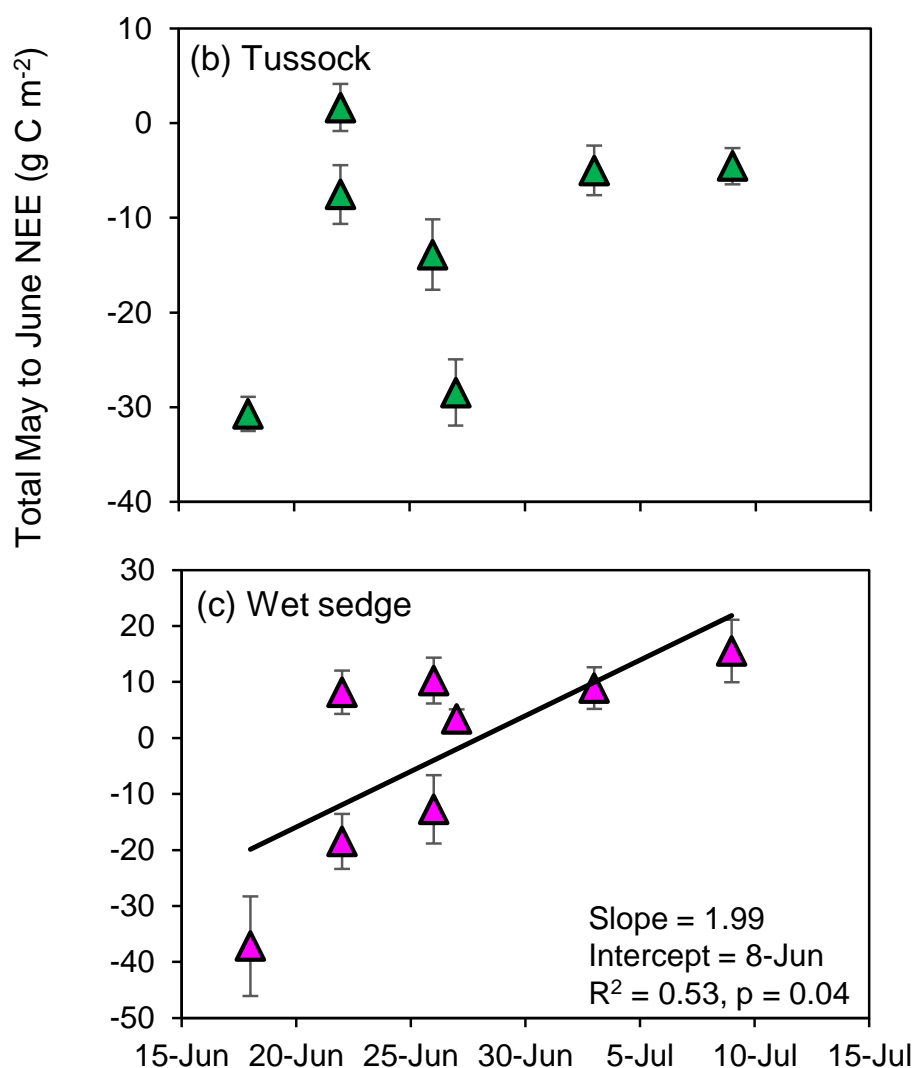

Day of soil thaw 


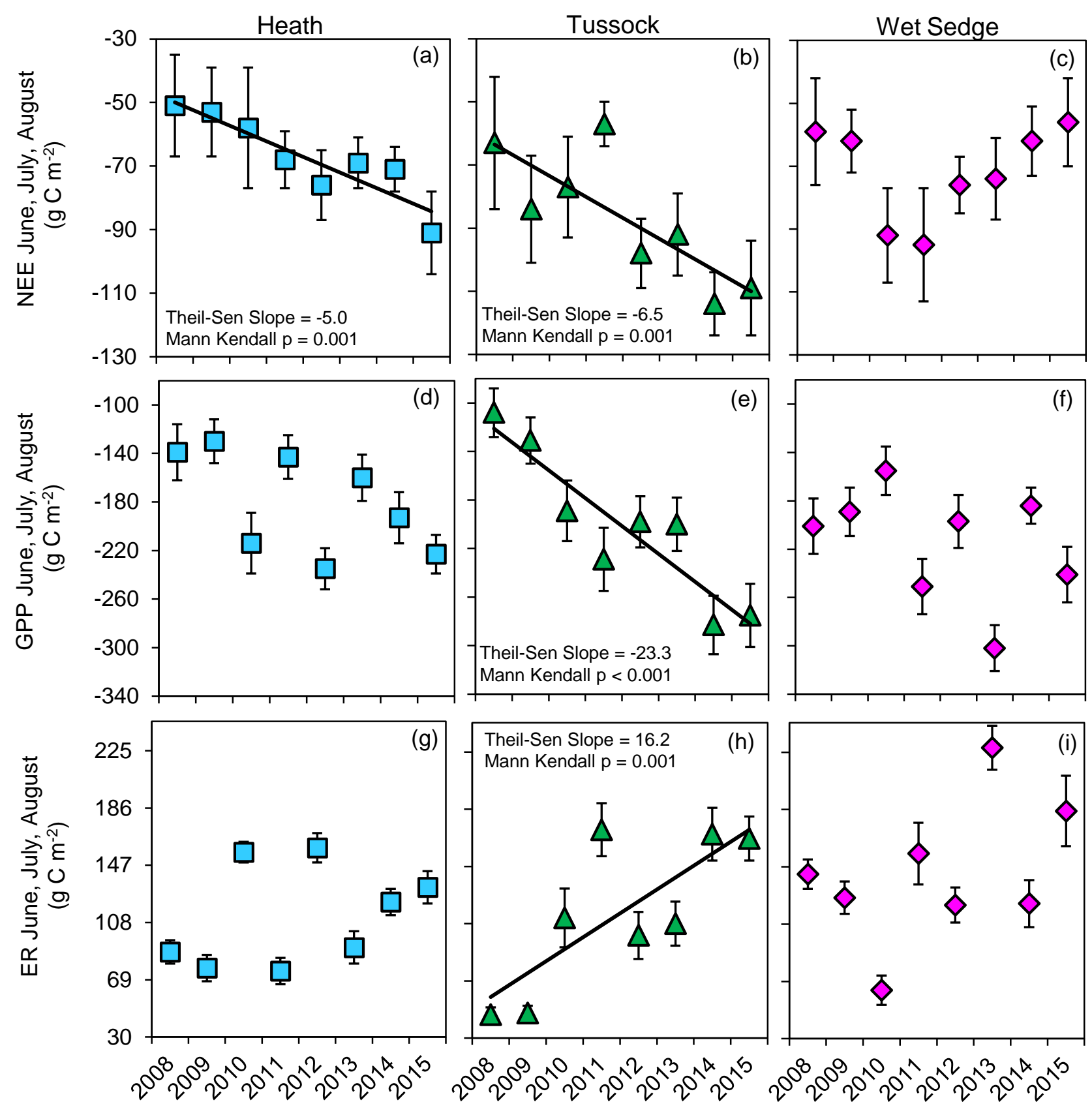

Figure 6 


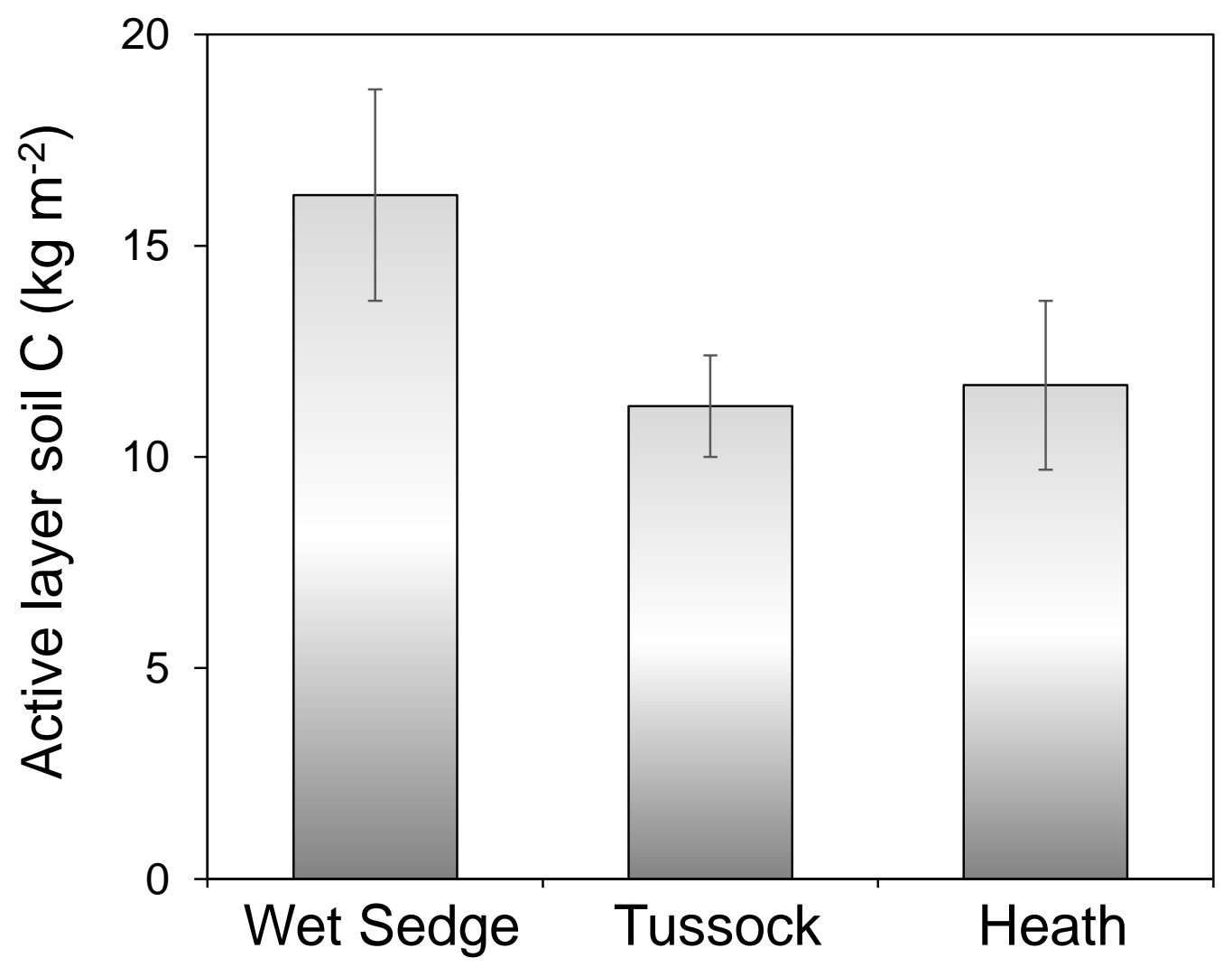




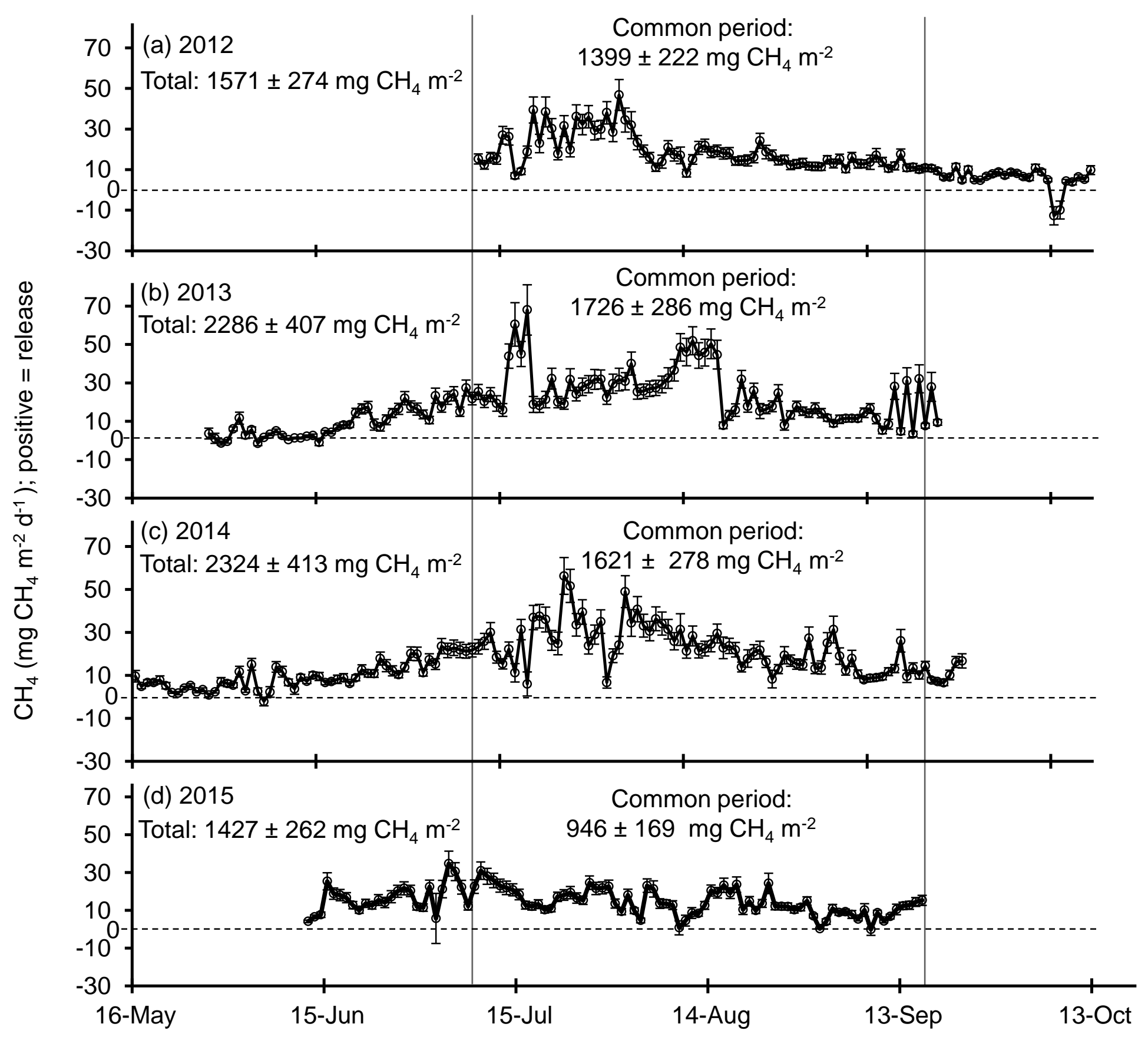

Figure 8 


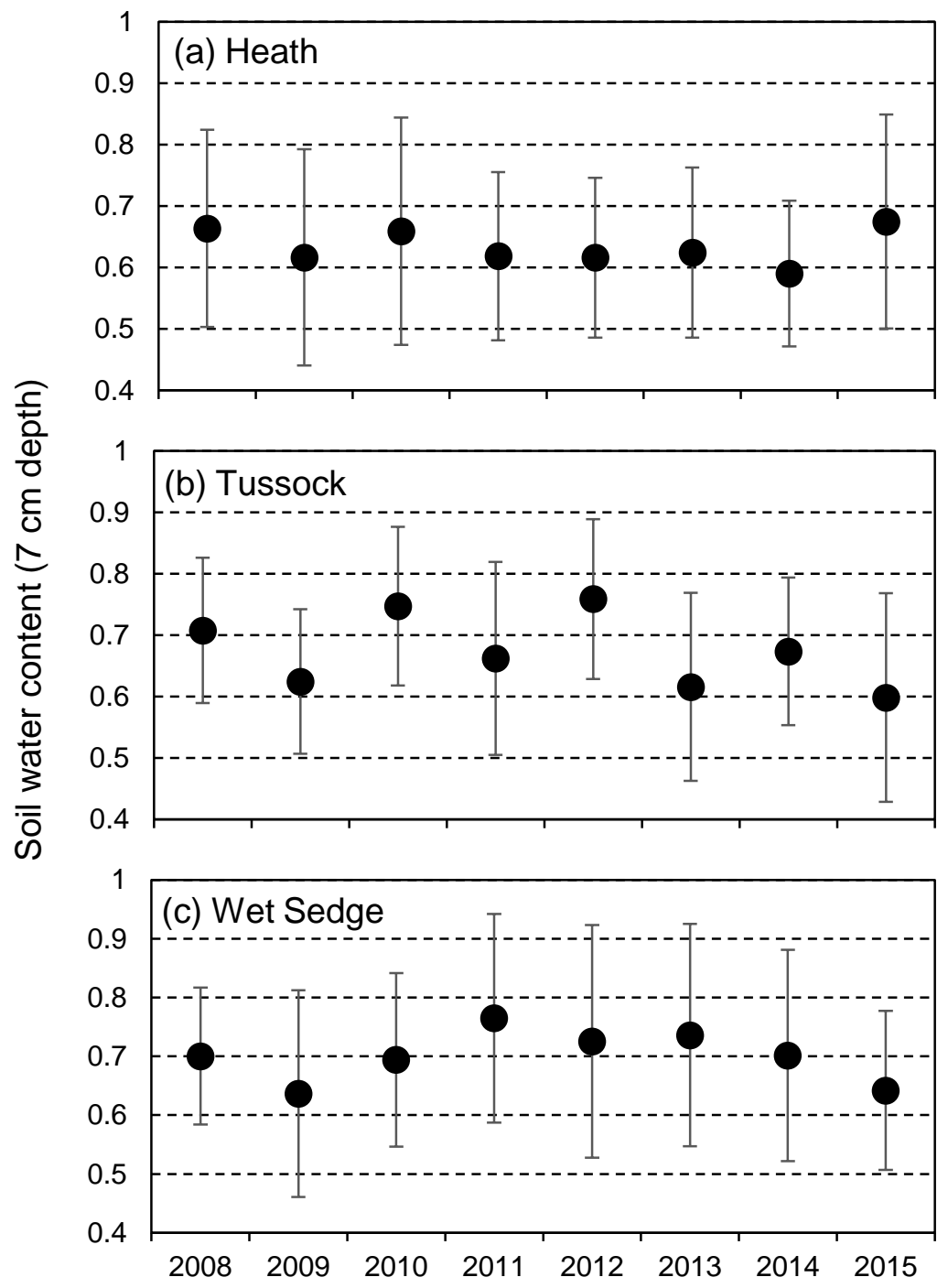




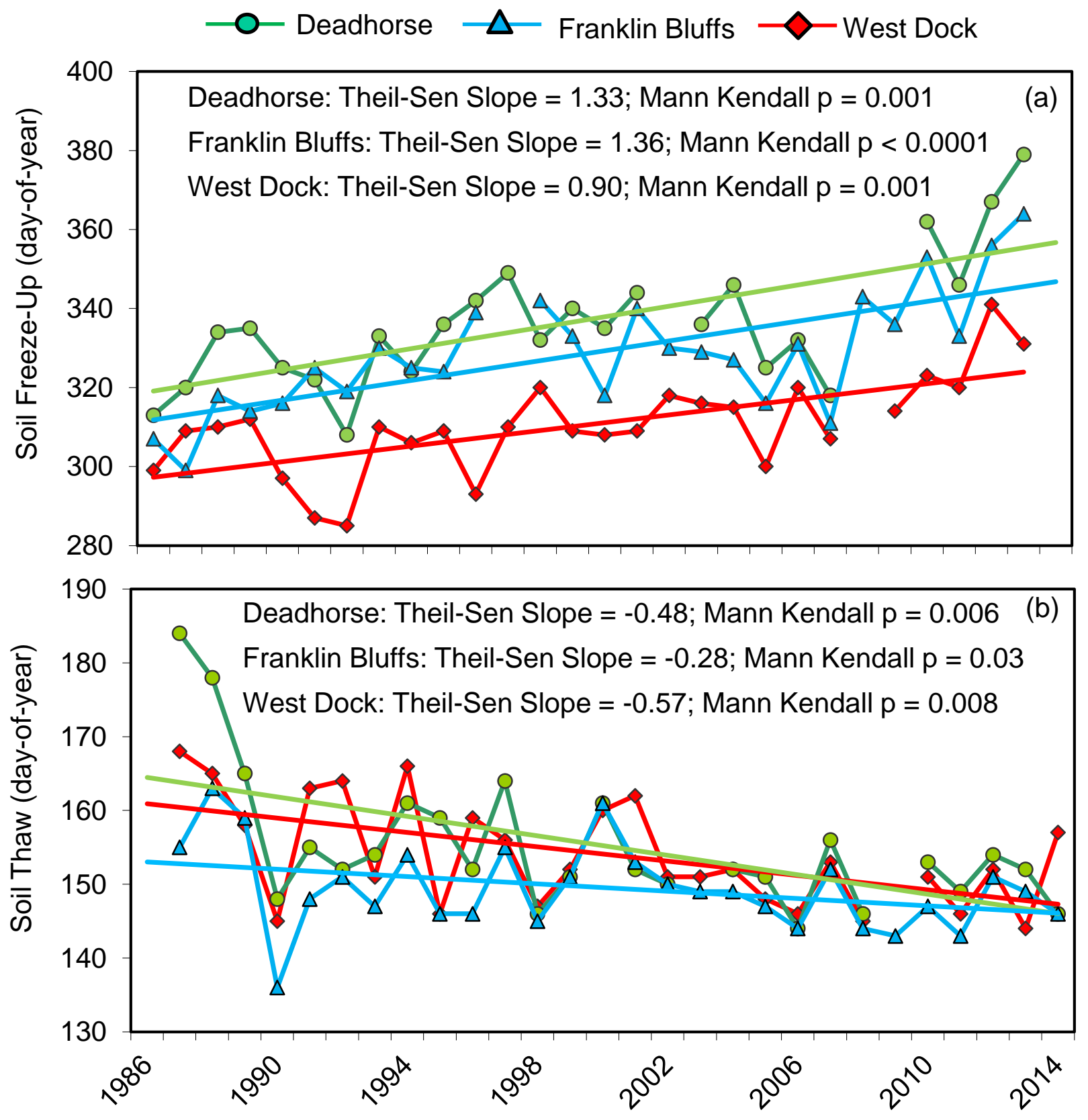

